\title{
Gitelman syndrome combined with complete growth hormone deficiency
}

\author{
Se Ra Min, MD', \\ Hyun Seok Cho, MD', \\ Jeana Hong, MD', \\ Hae Il Cheong, $\mathrm{MD}^{2,3,4}$, \\ Sung Yeon Ahn, MD' \\ 'Department of Pediatrics, \\ Kangwon National University \\ School of Medicine, Chuncheon, \\ ${ }^{2}$ Department of Pediatrics, \\ ${ }^{3}$ Research Coordination Center for \\ Rare Diseases, ${ }^{4}$ Kidney Research \\ Institute, Medical Research Center, \\ Seoul National University Children's \\ Hospital, Seoul National University \\ College of Medicine, Seoul, Korea
}

Received: 4 February, 2013

Revised: 14 March, 2013

Accepted: 18 March, 2013

Address for correspondence:

Sung Yeon Ahn, MD

Department of Pediatrics, Kangwon

National University Hospital, 156,

Baengnyeong-ro, Chuncheon

200-701, Korea

Tel: +82-33-258-9136

Fax: +82-33-258-2418

E-mail:ahn74@kangwon.ac.kr
Gitelman syndrome is a rare autosomal recessive hereditary salt-losing tubulopathy, that manifests as hypokalemic metabolic alkalosis, hypomagnesemia, and hypocalciuria. It is caused by mutations in the solute carrier family 12 (sodium/chloride transporters), member 3 (SLC12A3) gene encoding the thiazide-sensitive sodium chloride cotransporter channel (NCCT) in the distal convoluted tubule of the kidney. It is associated with muscle weakness, cramps, tetany, vomiting, diarrhea, abdominal pain, and growth retardation. The incidence of growth retardation, the exact cause of which is unknown, is lower than that of Bartter syndrome. Herein, we discuss the case of an overweight 12.9-year-old girl of short stature presenting with hypokalemic metabolic alkalosis. The patient, on the basis of detection of a heterozygous mutation in the SLC12A3 gene and poor growth hormone $(\mathrm{GH})$ responses in two provocative tests, was diagnosed with Gitelman syndrome combined with complete GH deficiency. $\mathrm{GH}$ treatment accompanied by magnesium oxide and potassium replacement was associated with a good clinical response.

Keywords: Gitelman syndrome; Sodium Chloride Symporters, Growth hormone

\section{Introduction}

Gitelman syndrome is a rare autosomal recessive renal tubular disorder ${ }^{1)}$. Characteristic laboratory abnormalities are hypokalemic metabolic alkalosis, hypomagnesemia, and hypocalciuria. It is usually caused by mutations in the SLC12A3 gene encoding the thiazidesensitive sodium chloride cotransporter channel (NCCT) in the distal convoluted tubule of the kidney $y^{2)}$. Diagnosis is most often made incidentally during adolescence or early adulthood. Although Gitelman syndrome is sometimes asymptomatic, it can present with clinical symptoms such as fatigue, muscle weakness, cramps, tetany, vomiting, diarrhea, and abdominal pain. Growth retardation and poor weight gain are common features, but are less severe than in Bartter syndrome ${ }^{3}$. Although potassium depletion may have some negative effect on growth, the exact cause of growth retardation in Gitelman syndrome is unknown. Reports of Gitelman syndrome combined with growth hormone (GH) deficiency are quite rare. Here, we report on a girl with Gitelman syndrome, diagnosed by molecular evaluation, combined with GH deficiency.

\section{Case report}

A 12.9-year-old girl visited our department of pediatrics complaining of chronic abdominal pain and diarrhea. She had also experienced tetany of the hand and foot for several months. At her full-term birth, her weight was $2.75 \mathrm{~kg}$. Her family history had no history of renal, endocrinologic, or cardiovascular disease. Her father's height was $170 \mathrm{~cm}$, her mother's 155 $\mathrm{cm}$, and the midparental height, $156 \mathrm{~cm}$. She had no history of diuretics use. Her height was $138.4 \mathrm{~cm}$ (<3rd percentile, -2.33 standard deviation score [SDS]); her weight was $43.3 \mathrm{~kg}$ 
(25th-50th percentile, -0.23 SDS); her body mass index was $22.7 \mathrm{~kg} / \mathrm{m}^{2}$ (85th-90th percentile). The puberal stage was breast II and pubic hair I, and her bone age, according to the GreulichPyle method, was 11 years. Her blood pressure was 100/60 $\mathrm{mmHg}$. Initial biochemical analysis revealed, on the basis of the following values, metabolic alkalosis with hypokalemia: sodium $139 \mathrm{mEq} / \mathrm{L}$, potassium $2.4 \mathrm{mEq} / \mathrm{L}$, chloride $98 \mathrm{mEq} / \mathrm{L}$, blood urea nitrogen $5.8 \mathrm{mg} / \mathrm{dL}$, creatinine $0.4 \mathrm{mg} / \mathrm{dL}$, aspartate aminotransferase $48 \mathrm{U} / \mathrm{L}$, alanine aminotransferase $67 \mathrm{U} / \mathrm{L}$, pH 7.467, $\mathrm{PCO}_{2} 47.4 \mathrm{mmHg}, \mathrm{HCO}_{3}-34.5 \mathrm{mmol} / \mathrm{L}$ (normal range, 22 to $26 \mathrm{mmol} / \mathrm{L}$ ), base excess $9.6 \mathrm{mmol} / \mathrm{L}$ ( -4 to $2 \mathrm{mmol} /$ L), total calcium $9.9 \mathrm{mg} / \mathrm{dL}$, phosphorus $4.7 \mathrm{mg} / \mathrm{dL}$. Further laboratory investigation showed the following: magnesium 1.48 $\mathrm{mg} / \mathrm{dL}$ (1.5 to $2.3 \mathrm{mg} / \mathrm{dL}$ ), serum osmolality $218 \mathrm{mOsmol} / \mathrm{kg}$ (275 to $295 \mathrm{mOsmol} / \mathrm{kg})$, renin $32.66 \mathrm{ng} / \mathrm{mL} / \mathrm{hr}(<4.2 \mathrm{ng} / \mathrm{mL} /$ $\mathrm{hr}$ ), and aldosterone $361.28 \mathrm{pg} / \mathrm{mL}$ (20 to $220 \mathrm{pg} / \mathrm{mL}$ ). Urine test results were as follows: $\mathrm{Na}^{+} 61 \mathrm{mEq} / \mathrm{L}, \mathrm{K}^{+} 29.0 \mathrm{mEq} / \mathrm{L}, \mathrm{Cl}^{-} 57$ $\mathrm{mEq} / \mathrm{L}$, osmolality $641 \mathrm{mOsmol} / \mathrm{kg}$ (50 to $1400 \mathrm{mOsmol} / \mathrm{kg}$ ), spot urine calcium/creatinine ratio $<0.02 \mathrm{mg} / \mathrm{mg}$ ( 0.03 to 0.2 $\mathrm{mg} / \mathrm{mg}), 24$ hours urine calcium $0.62 \mathrm{mg} / \mathrm{kg}$ (1.0 to $4.0 \mathrm{mg} / \mathrm{kg} /$ day), 24 hours urine magnesium $0.74 \mathrm{mg} / \mathrm{kg}(2.82 \pm 0.79 \mathrm{mg} / \mathrm{kg} /$ day). The calculated transtubular potassium gradient (TTKG) had increased to 8.078 .

The patient had normal thyroid and parathyroid function. Abdominal ultrasound showed normal kidneys and diffuse mild fatty infiltration of the liver. GH stimulation tests for short stature revealed complete deficiency (Table 1). Magnetic resonance imaging of the brain revealed no remarkable findings. Her intelligence quotient as measured by the Korean Wechsler Intelligence Scale for Children III test was 67. Wholeblood DNA sequencing showed heterozygous mutation in the SLC12A3 gene (Fig. 1). Although her sister and brother were not genetically evaluated, they showed normal electrolyte and blood gas readings.

The patient was treated with $0.7 \mathrm{IU} / \mathrm{kg} /$ wk of $\mathrm{GH}$ and administered oral replacement of magnesium oxide $(\mathrm{MgO}, 1$ g) and potassium chloride ( $\mathrm{KCl}, 1.8 \mathrm{~g})$. Serum photassium and magnesium level increased to $3.0 \mathrm{mEq} / \mathrm{L}$ and $1.85 \mathrm{mg} / \mathrm{dL}$. She showed a $5.6 \mathrm{~cm}$ height gain over seven months. The frequency of abdominal pain and diarrhea markedly decreased, and the tetany and muscle-cramping symptoms were eliminated.

\section{Discussion}

The patient, aged 12.9 years, presented with hypokalemia, metabolic alkalosis, and hyperreninemic hyperaldosteronism accompanied by short stature, obesity, and mild mental retardation. She was diagnosed with Gitelman syndrome by detection of heterozygous mutation in the SLC12A3 gene.

Gitelman syndrome results from various inactivation mutations in the SLC12A3 gene on chromosome 16q, which encodes the thiazide-sensitive sodium chloride cotransporter

Table 1. GnRH and GH stimulation tests showed normal pubertal response and complete GH deficiency

\begin{tabular}{|c|c|c|c|c|c|c|}
\hline Test & Hormones & Basal & $30 \mathrm{~min}$ & $60 \mathrm{~min}$ & $90 \mathrm{~min}$ & $120 \mathrm{~min}$ \\
\hline \multirow[t]{3}{*}{ GnRH } & $\mathrm{LH}(\mathrm{mlU} / \mathrm{mL})$ & 0.1 & 12.52 & 10.18 & 6.88 & 3.98 \\
\hline & FSH (mlU/mL) & 2.71 & 15.94 & 18.36 & 16.38 & 14.16 \\
\hline & Estradiol (ng/dL) & 1.55 & & & & \\
\hline L-dopa & $\mathrm{GH}(\mathrm{ng} / \mathrm{mL})$ & 0.18 & 0.37 & 0.88 & 0.3 & 3.5 \\
\hline \multirow[t]{2}{*}{ Clonidine } & $\mathrm{GH}(\mathrm{ng} / \mathrm{mL})$ & 0.18 & 0.12 & 0.11 & 0.55 & 0.71 \\
\hline & IGF-1 (ng/mL) & 161.33 & & & & \\
\hline
\end{tabular}

GnRH, gonadotropin releasing hormone; GH, growth hormone; LH, luteinizing hormone; FSH, follicle stimulating hormone; IGF-1, insulinlike growth factor 1 .

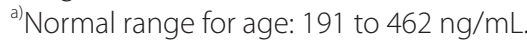
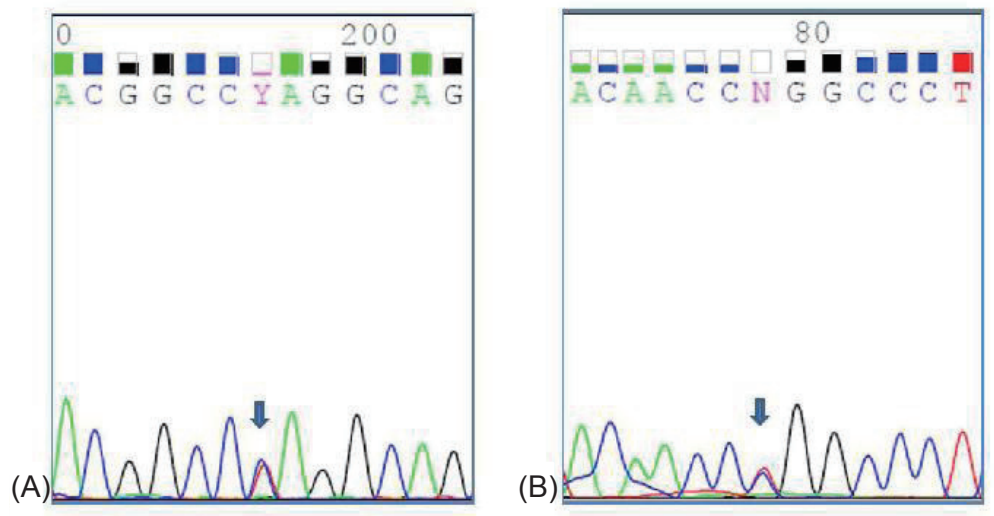

Fig. 1. Heterozygous mutations were detected in exon 3 and 15 of SLC12A3 gene. (A) a heterozygous c.494A > T (p.Gln165Leu) in exon 3, (B) a heterozygous c.1868T > C (p.Leu623Pro) in exon 15. 
channel in the distal convoluted tubule. 172 distinct phenotypevariable mutations in the SLC12A3 gene have been reported ${ }^{4)}$. Defects in the thiazide-sensitive NCCT impair $\mathrm{Na}^{+}$and $\mathrm{Cl}^{-}$ reabsorption, causing natriuresis and leading to volume contraction, which activates the renin-angiotensin-aldosterone axis. Increased aldosterone leads to secretion of $\mathrm{K}^{+}$and $\mathrm{H}^{+}$, which causes hypokalemia and alkalosis ${ }^{5)}$. Bartter syndrome also results from congenital renal tubule defects, the site of which is the thick ascending limb of the loop of Henle. Patients with Bartter syndrome present with symptoms in early childhood, and suffer a more severe failure to thrive. Patients with Gitelman syndrome, by contrast, are mostly asymptomatic or become fully symptomatic only in adolescence or adulthood ${ }^{6}$. Gitelman syndrome is associated with less severe growth retardation.

There are many factors that may contribute to growth retardation in Bartter or Gitelman syndrome. However, factors such as prematurity, significant salt loss in the antenatalneonatal period, and marked polyuria are not present in Gitelman syndrome. Hypokalemia and metabolic alkalosis may have some effect on growth. Although hypokalemia can play key role in growth retardation, some patients still have growth problems after the normalization of serum electrolytes. Experimental studies, which found that rats fed a potassiumpoor diet exhibited significant body-length reduction and weight gain, along with low levels of serum GH and insulinlike growth factor 1 (IGF-1), suggested that potassium depletion could have a negative effect on pituitary GH secretion ${ }^{7,8)}$. Partial or complete GH deficiency has been found in several patients with either Bartter syndrome ${ }^{9-12)}$ or Gitelman syndrome ${ }^{13-15)}$. In all of the corresponding reports, growth response to GH treatment was generally good. In four reported cases of Gitelman syndrome with $\mathrm{GH}$ deficiency, growth velocity rose to $10.2-12 \mathrm{~cm} / \mathrm{yr}$ during the first year of GH treatment. The girl in this report exhibited a $5.6 \mathrm{~cm}$ height gain during 7 months of $\mathrm{GH}$ treatment (growth velocity, $9.6 \mathrm{~cm} / \mathrm{yr}$ ). The reason for the association between hypokalemic tubulopathies and GH deficiency is not clear. GH treatment seemed to be helpful for the correction of hypomagnesemia. GH treatment has markedly increased magnesium absorption and retention in growing pigs $^{16)}$ and restored the serum magnesium levels in children with Gitelman syndrome $e^{13)}$. In our case, as the patient was treated with $\mathrm{MgO}$ and $\mathrm{GH}$ simultaneously, the effect of $\mathrm{GH}$ on serum magnesium level could not be evaluated.

GH and IGF-1 treatment has been shown to not stimulate longitudinal growth unless to correct hypokalmeia in hypokalemic rats ${ }^{17,18)}$. Experimental study demonstrated that potassium depletion leads to tissue-specific alteration in $\mathrm{GH}$ and IGF-1 metabolism in rats fed a potassium-deficient $\operatorname{diet}^{19)}$.

Pubertal delay seems not to correlate with Gitelman syndrome symptoms. In this case, pubertal stage was delayed relative to chronologic age, but pubertal responses of LH and FSH to GnRH were observed.

If a child with Gitelman syndrome shows marked growth retardation, the GH-IGF-1 axis should be checked. GH treatment as well as the correction of serum potassium level is important for optimal growth. Further clinical research on Gitelman syndrome patients is required for more comprehensive analysis of the relations among growth retardation, abnormal GH-IGF-1 axis, and response to GH treatment.

\section{Conflict of interest}

No potential conflict of interest relevant to this article was reported.

\section{Acknowledgments}

This case report was supported by a grant (A120017) from the Korea Healthcare technology R\&D Project, Ministry for Health, Welfare and Family Affairs, Republic of Korea.

\section{References}

1. Gitelman HJ, Graham JB, Welt LG. A new familial disorder characterized by hypokalemia and hypomagnesemia. Trans Assoc Am Physicians 1966;79:221-35.

2. Abuladze N, Yanagawa N, Lee I, Jo OD, Newman D, Hwang J, et al. Peripheral blood mononuclear cells express mutated NCCT mRNA in Gitelman's syndrome: evidence for abnormal thiazide-sensitive $\mathrm{NaCl}$ cotransport. J Am Soc Nephrol 1998;9:819-26.

3. Fremont OT, Chan JC. Understanding Bartter syndrome and Gitelman syndrome. World J Pediatr 2012;8:25-30.

4. Vargas-Poussou R, Dahan K, Kahila D, Venisse A, RiveiraMunoz E, Debaix H, et al. Spectrum of mutations in Gitelman syndrome. J Am Soc Nephrol 2011;22:693-703.

5. Graziani G, Fedeli C, Moroni L, Cosmai L, Badalamenti S, Ponticelli C. Gitelman syndrome: pathophysiological and clinical aspects. QJM 2010;103:741-8.

6. Sinha A, Lnenicka P, Basu B, Gulati A, Hari P, Bagga A. Gitelman syndrome: novel mutation and long-term followup. Clin Exp Nephrol 2012;16:306-9.

7. Flyvbjerg A, Dorup I, Everts ME, Orskov H. Evidence that potassium deficiency induces growth retardation through reduced circulating levels of growth hormone and insulinlike growth factor I. Metabolism 1991;40:769-75.

8. Gil-Pena H, Garcia-Lopez E, Alvarez-Garcia O, Loredo V, Carbajo-Perez E, Ordonez FA, et al. Alterations of growth plate and abnormal insulin-like growth factor I metabolism in growth-retarded hypokalemic rats: effect of growth hormone treatment. Am J Physiol Renal Physiol 2009;297:F639-45.

9. Ruvalcaba RH, Martinez FE. Case report: familial growth hormone deficiency associated with Bartter's syndrome. Am J Med Sci 1992;303:411-4.

10. Boer LA, Zoppi G. Bartter's syndrome with impairment of growth hormone secretion. Lancet 1992;340:860.

11. Akil I, Ozen S, Kandiloglu AR, Ersoy B. A patient with Bartter syndrome accompanying severe growth hormone 
deficiency and focal segmental glomerulosclerosis. Clin Exp Nephrol 2010;14:278-82.

12. Buyukcelik M, Keskin M, Kilic BD, Kor Y, Balat A. Bartter syndrome and growth hormone deficiency: three cases. Pediatr Nephrol 2012;27:2145-8.

13. Ko CW, Koo JH. Recombinant human growth hormone and Gitelman's syndrome. Am J Kidney Dis 1999;33:77881.

14. Bettinelli A, Rusconi R, Ciarmatori S, Righini V, Zammarchi E, Donati MA, et al. Gitelman disease associated with growth hormone deficiency, disturbances in vasopressin secretion and empty sella: a new hereditary renal tubularpituitary syndrome? Pediatr Res 1999;46:232-8.

15. Slyper AH. Growth, growth hormone testing and response to growth hormone treatment in Gitelman syndrome. J Pediatr Endocrinol Metab 2007;20:257-9.
16. Pointillart A, Denis I, Colin C, Lacroix H. Influence of exogenous porcine growth hormone on magnesium metabolism in intact pigs receiving normal magnesium intakes. Magnes Res 1994;7:39-42.

17. Dorup I, Flyvbjerg A. Effects of IGF-I infusion on growth and muscle $\mathrm{Na}(+)-\mathrm{K}+$ pump concentration in $\mathrm{K}(+)-$ deficient rats. Am J Physiol 1993;264(5 Pt 1):E810-5.

18. Hochberg Z, Amit T, Flyvbjerg A, Dorup I. Growth hormone $(\mathrm{GH})$ receptor and $\mathrm{GH}$-binding protein deficiency in the growth failure of potassium-depleted rats. J Endocrinol 1995;147:253-8.

19. Hsu FW, Tsao T, Rabkin R. The IGF-I axis in kidney and skeletal muscle of potassium deficient rats. Kidney Int 1997;52:363-70. 